\title{
Antidermatophytic Activity of Bamboo Vinegars Collected at Different Temperatures
}

\section{LIN, Han Chien}

Laboratory of Environment Functional Materials, Department of Wood Based Materials and Design, College of Agriculture, National Chiayi University | Laboratory of Wood Material Technology, Division of Sustainable Bioresources Science, Department of Agro-environmental Sciences, Faculty of Agriculture, Kyushu University

\section{WANG, Shao-Hung}

Department of Microbiology, Immunology and Biopharmaceuticals, College of Life Sciences, National Chiayi University | Laboratory of Wood Material Technology, Division of Sustainable Bioresources Science, Department of Agro-environmental Sciences, Faculty of Agriculture, Kyushu University

\section{HUANG, Yi-Han}

Graduate Institute of Wood Based Materials and Design, College of Agriculture, National Chiayi University | Laboratory of Wood Material Technology, Division of Sustainable Bioresources

Science, Department of Agro-environmental Sciences, Faculty of Agriculture, Kyushu University

\section{SHIAH, Tsang-Chy i}

Department of Wood Based Materials and Design, College of Agriculture, National Chiayi University | Laboratory of Wood Material Technology, Division of Sustainable Bioresources

Science, Department of Agro-environmental Sciences, Faculty of Agriculture, Kyushu University

他

https://doi.org/10.5109/1911180

出版情報 : 九州大学大学院農学研究院紀要. 63 (1)，pp.75-81，2018-02-27. Faculty of Agriculture， Kyushu University

バージョン :

権利関係 : 


\title{
Antidermatophytic Activity of Bamboo Vinegars Collected at Different Temperatures
}

\author{
Han Chien LIN ${ }^{1}$, Shao-Hung WANG ${ }^{2}$, Yi-Han HUANG ${ }^{3}$, Tsang-Chyi SHIAH ${ }^{4 *}$, \\ Gwo-Shyong HWANG ${ }^{5}$ and Noboru FUJIMOTO ${ }^{6}$
}

\author{
Laboratory of Wood Material Technology, Division of Sustainable Bioresources Science, \\ Department of Agro-environmental Sciences, Faculty of Agriculture, \\ Kyushu University, Fukuoka 812-8581, Japan \\ (Received October 31, 2017 and accepted November 20, 2017)
}

\begin{abstract}
Bamboo vinegars were collected from the chimney outflow of earthen kiln at different temperatures during the bamboo charcoal preparation from Moso bamboo (Phyllo-stachys pubescens). To evaluate antidermatophytic activity of Epidermophyton floccosum (EF), Trichophyton mentagrophytes (TM) and Trichophyton rubrum (TR), the minimum inhibitory concentration (MIC) of bamboo vinegars was determined by the broth microdilution method. The ether stratification of bamboo vinegars for three fractions (acidic, neutral and phenolic materials) and the ether fraction was also investigated. There was antidermatophytic activity for EF, TM and TR, when the bamboo vinegars were diluted 20 times (2.50\%). The MIC had the best $0.32 \mathrm{mg} / \mathrm{mL}$ on $\mathrm{EF}$ for the vinegar collected at $100^{\circ} \mathrm{C}$, and the MIC of ether stratification showed that the ether fraction, the fractions of neutral, and phenolic materials had better antidermatophytic activity for EF, which was $0.16,0.31$ and $0.02 \mathrm{mg} / \mathrm{mL}$, respectively. The MIC of ether fraction, and the neutral and phenolic materials of the bamboo vinegar collected at $120-125^{\circ} \mathrm{C}$ for $\mathrm{TM}$ was $0.08-0.31 \mathrm{mg} / \mathrm{mL}$. For TR, the vinegar collected at $80^{\circ} \mathrm{C}$ had better antidermatophytic activity, and the MIC of ether fraction, the neutral, and phenolic materials was $0.16,0.31$ and $0.04 \mathrm{mg} / \mathrm{mL}$. The MIC of antidermatophytic activity for the ether fraction of bamboo vinegars was $0.16-0.63 \mathrm{mg} / \mathrm{mL}$ and the phenolic compounds had the highest content, $62.68-78.32 \%$. The phenolic material of phenolic fraction from bamboo vinegars was $82.27-94.45 \%$ and the MIC was $0.01-0.16 \mathrm{mg} / \mathrm{mL}$. The phenol, cresol, 2,6-dimethoxyl-phenol and 2-methoxyl-phenol, from the phenolic material exhibited strong antidermatophytic activities due to the higher contents.
\end{abstract}

Key words: Bamboo Vinegar, Epidermophyton floccosum (EF), Trichophyton mentagrophytes (TM), Trichophyton rubrum (TR), Minimum Inhibitory Concentration (MIC)

\section{INTRODUCTION}

To increase the value-added of bamboo, the Council of Agriculture in Taiwan performed the "Bamboo Industry Transformation and Revival Project" in 2002 to popularize and develop bamboo products, cooperated with private suppliers, and instructed them in bamboo charcoal making technology. The purpose was to enhance the value-added and competitiveness of the bamboo industry. In the preparation of bamboo into bamboo charcoal, the smoke and steam at the chimney outflow are collected by the cooling system to obtain a yellow brown supernatant liquid, which is bamboo vinegar that has a particular smoky flavour; $80-90 \%$ of the

Laboratory of Environment Functional Materials, Department of Wood Based Materials and Design, College of Agriculture, National Chiayi University, Chiayi, Taiwan, ROC.

${ }^{2}$ Department of Microbiology, Immunology and Biopharmaceuticals, College of Life Sciences, National Chiayi University, Chiayi, Taiwan, ROC.

${ }^{3}$ Master, Graduate Institute of Wood Based Materials and Design, College of Agriculture, National Chiayi University, Chiayi, Taiwan, ROC.

${ }^{4}$ Department of Wood Based Materials and Design, College of Agriculture, National Chiayi University, Chiayi, Taiwan, ROC.

${ }^{5}$ Divisions of Forest Utilization, Taiwan Forestry Research Institute (TFRI), Taipei, Taiwan, ROC.

${ }^{6}$ Laboratory of Wood Material Technology, Division of Sustainable Bioresources Science, Department of Agroenvironmental Sciences, Faculty of Agriculture, Kyushu University, Japan.

* Corresponding author (E-mail: tcshiah@mail.ncyu.edu.tw) main constituents are water, and $10-20 \%$ are organic constituents; mostly they are acetic acid, and the rest are about 200 kinds of organic coompounds (Mu et al., 2003). Bamboo vinegar is antimicrobial in the case of high concentration and promotes microbial activity in the case of low concentration, which can be used as a pesticide disinfector, compost fermentation accelerant, plant growth regulator, and insect repellant and deodorant (Ikimoto and Ikeshima, 2000; Yatagai, 2002; Mu et al., 2003; Lin et al., 2008). However, there is not yet any systematic in vitro study of the effect of smearing or soaking in diluted bamboo vinegar on antidermatophytes.

There are numerous kinds of dermatophytosis that are caused mainly by genera of Trichophyton, Epidermophyton, and Microsporum, are a frequent dermatological problem in Taiwan, and are also known as "athlete's foot", when the foot is infected by fungi. The surface shallow mycotic infection on human body is known as "tinea". These mycotic infections are mostly caused by dermatophytes, and the dermatophytosis is infection of the skin and subcutaneous keratin tissue caused by the encroachment of hyphomycetes, which is an infectious skin disease with the highest morbidity rate. At present, there are over 20 kinds of dermatophytes that cause human diseases, classified into Epidermophyton floccosum (EF), Trichophyton mentagrophytes (TM), Trichophyton rubrum (TR). EF, $\mathrm{TM}$, and TR are the main epidermis infection fungi of humans, and the tinea represents the infection of dermatophytes, named according to the position of infec- 
tion; there are tinea capitis, tinea cruris, and tinea pedis (Huang and Wang, 2003; Chuang et al., 2007; Han et al., 2014).

The common drugs for treating tinea pedis are mostly ointments for external application of azole drugs, such as ketoconazole, clotrimazole, miconazole, and so on, which inhibit the reproduction of fungi and accelerate the exfoliation of epidermis, so that the fungi and spores depart from the epidermis. In addition, there are peroral griseofulvin (Fulcin, Grisovin), known as "grisein", itraconazole (Sporanox), fluconazole (Flucon), and terbinafine (Lamisil), and the last one has the best treatment effect (Roberts, 1999). However, the compounds are mainly metabolized by the liver, and there are side effects on the intestine, skin, liver, and gall bladder. The liver function should be tested when the application exceeds 6 weeks. There have been case-reports of deaths caused by liver function damaged by oral administration of antimycotic drugs, and thus many people are concerned about the side effects of this kind of chemosynthetic drugs, such as nausea, abdominal pain (Ministry of Health and Welfare, 2006).

This study investigated the following experimentals: prepared the common bamboo - Phyllostachys pubescens in Taiwan into bamboo charcoal from the earthen kiln and collected the bamboo vinegars at different temperatures from the chimney outflow of earthen kiln; measured the basic properties of bamboo vinegars, including $\mathrm{pH}$ value, specific gravity, dissolved tar content, acidic material content, and color number; and evaluated the antidermatophytic activity of EF, TM and TR from bamboo vinegars. The bamboo vinegars were also divided by ether stratification into the ether fraction, and three fractions of acidic, neutral and phenolic materials. The minimum inhibitory concentration (MIC) of bamboo vinegars, fractions of ether stratification though EF, TM and TR was evaluated. Besides, the possible antidermatophytic compounds for antidermatophytic activity were analyzed by Gas Chromatography-Mass Spectrophotometer (GC-MS).

\section{MATERIALS AND METHODS}

\section{Experimental materials}

Bamboo vinegars

The bamboo vinegars were taken from Phyllostachys heterocycla Milf (Maso bamboo) in Zhushan, Taiwan, the bamboo charcoal was prepared by an earth kiln, and the generated smoke and steam were collected according to the the chimney outflow of kiln at different temperatures in the preparation procedures. The bamboo vinegars were cooled according to the different collected temperatures, 80, 90-93, 100, 120-125, and $140-145^{\circ} \mathrm{C}$ (Hwang et al., 2006).

\section{Fungal Strains}

Epidermophyton floccosum (EF, BCRC 30531), Trichophyton mentagrophytes (TM, BCRC 32066), and Trichophyton rubrum (TR, BCRC 32805) of dermatophytes were bought from the Taiwan Bioresource
Collection and Research Center in Taiwan

\section{Culture medium}

Sabouraud dextrose agar (SDA) for culture and continued generation of dermatophytic fungi were bought from Difco Laboratories Inc. Roswell Park Memorial Institute medium- 3-(N-morpholino) propanesulfonic acid (RPMI-1640) and MOPS were bought from U.S. SIGMA. MOPS is an additional buffering agent, applicable to any antimycotic drugs, for the MIC test.

\section{Experimental methods}

\section{Basic properties of bamboo vinegars}

The following tests for the basic properties of bamboo vinegars were all repeated three times. The $\mathrm{pH}$ value of bamboo vinegars collected at different temperatures were measured by a pen type pH meter (SUNTEX TS-1). The specific gravity of bamboo vinegars collected at different temperatures was measured by a hydrometer when they were put in a $20 \mathrm{~mL}$ measuring cylinder.

The acidic material content of bamboo vinegars was measured. 1-2 mL bamboo vinegar specimen was poured into a $250 \mathrm{~mL}$ conical flask, diluted with $100 \mathrm{~mL}$ distilled water, mixed with several drips of phenolphthalein indicator, and titrated with $0.1 \mathrm{~N} \mathrm{NaOH}$ ( $\mathrm{f}=0.099$ ). A blank test was implemented, whereby the acidic material content was calculated by equation:

$$
\text { acidic material content }(\%)=\{[(A-B) \times N \times 6] / S\} \times 100
$$

where $A$ : NaOH mL titrated in the bamboo vinegar specimen; $B$ : NaOH mL titrated in the blank test; $N$ : $\mathrm{NaOH}$ equivalent concentration; $S$ : bamboo vinegar specimen weight (g)

Fot the test of dissolved tar content, the weight $(W)$ of the crucible was measured accurately; about $10 \mathrm{~g}$ of bamboo vinegar was poured into it, and the weight $\left(W_{1}\right)$ was measured. Afterwards, it was put in an oven $\left(105^{\circ} \mathrm{C}, 3 \mathrm{~h}\right)$, cooled, and weighed $\left(W_{2}\right)$. Finally, the dissolved tar content was calculated by the following equation.

$$
\text { Dissolved tar content }(\%)=\left[\left(W_{2}-W\right) / W_{1}\right] \times 100
$$

where $W$ : weight of crucible (g); $W_{1}$ : weight of bamboo vinegar $(\mathrm{g}) ; W_{2}$ : weight of bamboo tar and crucible (g).

The color number of the vingars was measured by Orbeco hellige 705-V2 color number meter; the color disc was used for checking the determination according to the ASTM D-1544 Gardner method.

\section{Ether stratification}

$\mathrm{NaCl}$ (purity above 99.0\%) WAS mixed into each bamboo vinegar, mixed with ether (purity above 99.7\%) for stratification, and the ether fraction was stratified by a $5 \% \mathrm{NaHCO}_{3}$ (purity above 99.9\%) solution; the acidic material was dissolved in the water fraction, and the water fraction was acidified by a $30 \%$ sulfuric acid (purity above 98\%) solution, mixed with ether for stratification. Afterwards, the ether fraction was concentrated 
to obtain the fraction of acidic material; the ether fraction extracted by the $\mathrm{NaOH}$ (purity above 99.3\%) solution was mixed with the $2 \mathrm{~N} \mathrm{NaOH}$ solution, and the ether fraction was concentrated after stratification to obtain the fraction of neutral material. The water fraction was extracted by the $30 \%$ sulphuric acid solution and ether, and then the ether fraction was concentrated to obtain the fraction of phenolic materials (Sugiruma, 1995).

Identification of compounds in the bamboo vinegars and the fractions of ether stratification

To analyze the compounds in the bamboo vinegars, the ether fraction, and the acidic, neutral and phenolic materials, GC-MS (Agilent model 6890 GC with model 5973 MSD) was applied. The experimental steps refer to (Lin et al., 2016). Volatile compounds were identified by comparing the mass spectra with the data system libraries (Wiley/NBS and Nation Institute of Standard and Technology) and by Kovats indices (KI) estimated in accordance with modified Kovats method (Cheng et al., 2009). The relative percentages of individual compounds were calculated from the corresponding peak areas (Lin et al., 2008; 2016)

\section{Culture medium of antidermatophytic activity tested use}

For SDR culture medium, each $1 \mathrm{~L}$ of distilled water was mixed with $65.0 \mathrm{~g}$ SDA culture medium powder, sterilized by a sterilization kettle at a high temperature for $15 \mathrm{~min}$, cooled and poured into the culture dish, and solidified and stored in refrigerator at $4^{\circ} \mathrm{C}$. For RPMIMOPS culture medium, $10.4 \mathrm{~g}$ RPMI 1640 culture medium powder (containing glutamine, phenol red, and bicarbonate) was dissolved in $900 \mathrm{~mL}$ distilled water, when it was dissolved completely, mixed with $34.53 \mathrm{~g}$ MOPS powder buffer solution, mixed for $30 \mathrm{~min}$ to dissolve it uniformly, and then the $\mathrm{pH}$ was adjusted by $1 \mathrm{~N} \mathrm{NaOH}$ at $25^{\circ} \mathrm{C}$ to 7.0. Finally, the volume was increased by distilled water to $1 \mathrm{~L}$, sterilized by a culture filter, and stored at $4^{\circ} \mathrm{C}$. This culture medium is applicable to drug sensitivity analysis of any antimycotic drugs.

\section{MIC test}

The test follows the broth microdilution method published by National Committee for Clinical Laboratory Standards (CLSI) in August 2002. First step is preparation of spore suspension. The culture medium overgrown with spores is mixed with a 1000-2000 $\mu \mathrm{L} 0.85 \%$ aseptic saline solution, the bacteria solution was scraped by an L-shaped rod, and the bacteria solution is sucked by micropipette into the centrifuge tube, mixed with Tween 20 uniformly, centrifuged at $3000 \mathrm{rpm} / \mathrm{min}$, the upper clarified spore liquid is taken, and then the concentration of spore suspension is adjusted by a $0.85 \%$ aseptic saline solution to about $1.5 \times 10^{8} \mathrm{CFU} / \mathrm{mL}$ (McFarland Standard No.0.5-bacterial suspension standard solution) (Benger et al., 2004). Second step is preparation and dilution of antifungal drugs. According to the M100-S18 (Performance Standards for Antimicrobial Susceptibility Testing; $18^{\text {th }}$ Information
Supplement) standard of CLSI, the broth dilution method is used for the 96-well plate. The concentration of bamboo vinegar and various stratified fractions was diluted 10 times by the RPMI-MOPS culture medium as the raw liquor to be put in the 96-well plate and then diluted from left to right; the last well was free of addition as a negative control group. The blank group was $95 \%$ ethanol.

Finally, the broth microdilution method was used. The spore suspension at a concentration of McFarland Standard No.0.5 was diluted 50 times (approximately 1 $\left.\times 10^{6} \mathrm{CFU} / \mathrm{mL}\right) ; 100 \mu \mathrm{L}$ spore suspension at a fixed concentration was poured into the micro wells with a $100 \mu \mathrm{L}$ sample diluent, so that each micro well contained a $100 \mu \mathrm{L}$ specimen diluent and $100 \mu \mathrm{L}$ spore suspension, cultured in an incubator at a constant temperature of $25^{\circ} \mathrm{C}$. The growth of fungi was identified by the naked eye, the micro well that had not grown was obviously labeled, and the minimum diluted concentration of the specimen in the well not grown was the MIC of the fungus for the specimen. In addition, the amount of growth of fungi is measured by the enzyme-linked immunosorbent assay (LISA). The wavelength is $595 \mathrm{~nm}$, measure absorbance value (Cheng, 2011), in order to identify the MIC. The above tests were all repeated three times.

\section{Statistical analysis}

The test results are represented by a mean (standard deviation). Experimental measurements were carried out in triplicate. Statistical analysis was performed using one-way analysis of variance followed by Duncan's multiple comparison test using Statistical Product and Service Solutions (SPSS). Differences were considered statistically significant when $p<0.05$.

\section{RESULTS AND DISCUSSION}

\section{Basic properties of bamboo vinegars}

The $\mathrm{pH}$ value of bamboo vinegar obviously increased with the collection temperature (Table 1), but the acidic material content was insignificantly with temperature in accordance with the Duncan's multiple tests. It is indicated that because the thermal degradation turns into pyrolysis during collection, the $\mathrm{pH}$ value is relatively acidic. Hwang et al. (2006; 2008) report that the compositions of bamboo turn into water, $\mathrm{CO}_{2}$, acetic acid, propanoic acid, and many different organic acid compounds. The specific gravity of various bamboo vinegars was 1.005-1.007; the acidic material content was 5.97-8.61\% and the highest was the temperature at $145-150^{\circ} \mathrm{C}$. The color number was 7-11, and the color was clarified deep yellow brown. This is because the bamboo is composed of cellulose, hemicellulose, and lignin, the thermal decomposition temperature of hemicellulose is lower than $260^{\circ} \mathrm{C}$, and the chimney outflow temperature is $80-102^{\circ} \mathrm{C}$; that of cellulose is $260-310^{\circ} \mathrm{C}$, and the chimney outflow temperature is $105-123^{\circ} \mathrm{C}$; that of lignin is 310 $450^{\circ} \mathrm{C}$, and the chimney outflow temperature is $125-$ $159^{\circ} \mathrm{C}$. The neutral substances are generated in the pyrolysis stage, such as aldehyde, ketone, alcohols, and 
Table 1. Basic properties of bamboo vinegars collected at different temperatures

\begin{tabular}{cccccc}
\hline $\begin{array}{c}\text { Collected } \\
\text { temperature } \\
\left({ }^{\circ} \mathrm{C}\right)\end{array}$ & $\begin{array}{c}\mathrm{pH} \\
\text { value }\end{array}$ & $\begin{array}{c}\text { Specific } \\
\text { gravity }\end{array}$ & $\begin{array}{c}\text { Acidic } \\
\text { material } \\
\text { content (\%) }\end{array}$ & $\begin{array}{c}\text { Dissolved tar } \\
\text { content (\%) }\end{array}$ & $\begin{array}{c}\text { Color } \\
\text { number }\end{array}$ \\
\hline 80 & $2.66 \pm 0.11^{\mathrm{a} 1)}$ & $1.005 \pm 0.00^{\mathrm{a}}$ & $7.02 \pm 0.29^{\mathrm{b}}$ & $0.40 \pm 0.01^{\mathrm{b}}$ & $8-9 \pm 0.12^{2^{\mathrm{ab}}}$ \\
$90-93$ & $2.77 \pm 0.02^{\mathrm{b}}$ & $1.005 \pm 0.00^{\mathrm{b}}$ & $7.98 \pm 0.44^{\mathrm{c}}$ & $0.57 \pm 0.02^{\mathrm{c}}$ & $10-11 \pm 0.04^{\mathrm{bc}}$ \\
100 & $2.94 \pm 0.01^{\mathrm{c}}$ & $1.006 \pm 0.00^{\mathrm{b}}$ & $6.90 \pm 0.12^{\mathrm{b}}$ & $0.40 \pm 0.17^{\mathrm{b}}$ & $8 \pm 0.24^{\mathrm{a}}$ \\
$120-125$ & $3.57 \pm 0.03^{\mathrm{d}}$ & $1.006 \pm 0.00^{\mathrm{b}}$ & $5.97 \pm 0.72^{\mathrm{a}}$ & $0.30 \pm 0.03^{\mathrm{a}}$ & $7 \pm 0.13^{\mathrm{a}}$ \\
$140-145$ & $3.80 \pm 0.02^{\mathrm{e}}$ & $1.007 \pm 0.00^{\mathrm{c}}$ & $8.61 \pm 0.20^{\mathrm{d}}$ & $0.38 \pm 0.03^{\mathrm{b}}$ & $10-11 \pm 0.07^{\mathrm{bc}}$ \\
\hline
\end{tabular}

${ }^{1)}$ Mean \pm standard deviation with the different superscripts are significantly different $(p<0.05)$ by Duncan's multiple range tests

derivants; the proportion of acidic material is reduced, the lignin decomposition increases the dissolved tar content, and the color number varies slightly with the amount of acidic material and dissolved tar contents in the vinegar (Kuriyama, 1979; Hwang et al., 2006; 2008).

\section{Antidermatophytic activity of bamboo vinegar}

Table 2 showed that the MIC for three dermatophytes of Maso bamboo vinegars collected at different temperatures diluted 20 (2.50\%) times. There was an obvious antidermatophytic activity on EF and TR, and the MIC value was $0.32-0.63$ and $0.63-1.25 \mathrm{mg} / \mathrm{mL}$; that

Table 2. Minimum inhibitory concentrations $(\mathrm{mg} / \mathrm{mL})$ against dermatophytesof bamboo vinegars collected at different temperatures

\begin{tabular}{cccc}
\hline $\begin{array}{c}\text { Collected } \\
\text { temperature }\left({ }^{\circ} \mathrm{C}\right)\end{array}$ & $\mathrm{EF}^{1)}$ & $\mathrm{TM}$ & $\mathrm{TR}$ \\
\hline 80 & 0.63 & 2.50 & 0.63 \\
$90-93$ & 0.63 & 2.50 & 0.63 \\
100 & 0.32 & 1.25 & 0.63 \\
$120-125$ & 0.63 & 2.50 & 1.25 \\
$140-145$ & 0.63 & 1.25 & 0.63 \\
\hline
\end{tabular}

${ }^{1)} \mathrm{EF}:$ Epidermophytonfloccosu;

TM : Trichophytonmentagrophytes;

TR : Trichophytonrubrum collected at temperature $100^{\circ} \mathrm{C}$ has the best antidermatophytic activity. According to Table 1 , the $\mathrm{pH}$ value increased with collection temperature, but there is a slight difference in the MIC value, likely because the antidermatophytic activity of bamboo vinegars are not directly related to the $\mathrm{pH}$ value, but related to its compounds (Lin et al., 2008).

The antidermatophytic activity obviously increased after ether stratification (Table 3); the antidermatophytic activity of the ether fraction (EE), and the neutral (NC), phenolic (PC) fractions was significantly, and that of the acidic fraction (AC) was worse; the MIC for $\mathrm{EF}$ was $2.50 \mathrm{mg} / \mathrm{mL}$; that for TM was $0.63-2.50 \mathrm{mg} / \mathrm{mL}$; the temperatures $120-125$ and $140-145^{\circ} \mathrm{C}$ had the best $0.63 \mathrm{mg} / \mathrm{mL}$; that for TR was $1.25-2.50 \mathrm{mg} / \mathrm{mL}$; and the temperature above $100^{\circ} \mathrm{C}$ had the best $1.25 \mathrm{mg} / \mathrm{mL}$. The results of EE and NC had similar MIC results for TM and TR, which were $0.31-1.25 \mathrm{mg} / \mathrm{mL}$. The ether fraction at $100^{\circ} \mathrm{C}$ and $120-125^{\circ} \mathrm{C}$ had better antidermatophytic activity for $\mathrm{EF}$ and the MIC was $0.16 \mathrm{mg} / \mathrm{mL}$, and the temperatures $100^{\circ} \mathrm{C}$ above were identical and $140-145^{\circ} \mathrm{C}$ had the best $0.08 \mathrm{mg} / \mathrm{mL}$. Table 3 is also showed that the MIC of PC was lower than the others, the MIC for $\mathrm{EF}$ was $0.01-0.04 \mathrm{mg} / \mathrm{mL}$, the temperatures $120-125^{\circ} \mathrm{C}$ had the best $0.01 \mathrm{mg} / \mathrm{mL}$, and then $0.04 \mathrm{mg} / \mathrm{mL}$ for TR. According to the temperatures at which the ether stratification fractions of bamboo vinegar had the best antidermatophytic activity for three dermatophytes, the antidermatophytic activity for TR was the best when the temperature was $80^{\circ} \mathrm{C}$ and the MIC of EE, and $\mathrm{NC}, \mathrm{PC}$ was 0.16 ,

Table 3. Minimum inhibitory concentrations $(\mathrm{mg} / \mathrm{mL})$ against dermatophytes of ether stratification fraction of bamboovinegars collected at different temperatures

\begin{tabular}{|c|c|c|c|c|c|c|c|c|c|c|c|c|}
\hline \multirow{2}{*}{$\begin{array}{c}\text { Collected } \\
\text { Temperature }\left({ }^{\circ} \mathrm{C}\right)\end{array}$} & \multicolumn{4}{|c|}{$\mathrm{EF}^{1)}$} & \multicolumn{4}{|c|}{$\mathrm{TM}$} & \multicolumn{4}{|c|}{$\mathrm{TR}$} \\
\hline & $\mathrm{EE}^{2)}$ & $\mathrm{AC}$ & $\mathrm{NC}$ & $\mathrm{PC}$ & $\mathrm{EE}$ & $\mathrm{AC}$ & $\mathrm{NC}$ & $\mathrm{PC}$ & $\mathrm{EE}$ & $\mathrm{AC}$ & $\mathrm{NC}$ & $\mathrm{PC}$ \\
\hline 80 & 0.31 & 2.50 & 0.31 & 0.04 & 0.31 & 2.50 & 0.31 & 0.16 & 0.16 & 2.50 & 0.31 & 0.04 \\
\hline 90-93 & 0.31 & 2.50 & 0.63 & 0.02 & 0.63 & 2.50 & 0.63 & 0.08 & 0.31 & 2.50 & 0.31 & 0.04 \\
\hline 100 & 0.16 & 2.50 & 0.31 & 0.02 & 0.63 & 2.50 & 0.31 & 0.08 & 0.16 & 1.25 & 0.63 & 0.04 \\
\hline $120-125$ & 0.16 & 2.50 & 0.63 & 0.01 & 0.31 & 0.63 & 0.31 & 0.08 & 0.16 & 1.25 & 0.63 & 0.04 \\
\hline $140-145$ & 0.08 & 2.50 & 0.63 & 0.02 & 0.31 & 0.63 & 1.25 & 0.16 & 0.16 & 1.25 & 0.63 & 0.04 \\
\hline
\end{tabular}

1) Same as Table 2

${ }^{2)}$ EE: Ether fraction; AC: Acidic fraction; NC: Neutral fraction; PC: Phenolic fraction 
0.31 and $0.04 \mathrm{mg} / \mathrm{mL}$, respectively. The best antidermatophytic activity for $\mathrm{EF}$ when the temperature was $100^{\circ} \mathrm{C}$, and the $\mathrm{MIC}$ of $\mathrm{EE}$, and $\mathrm{NC}, \mathrm{PC}$ was $0.16,0.31$ and $0.02 \mathrm{mg} / \mathrm{mL}$. The antidermatophytic activity for TM was the best at $120-125^{\circ} \mathrm{C}$, and the MIC was $0.31,0.31$, and $0.08 \mathrm{mg} / \mathrm{mL}$ for the $\mathrm{EE}, \mathrm{NC}$ and $\mathrm{PC}$.

In addition, the antidermatophytic activity of PC was better than others, higher than EE by $4-8$ times and higher than NC by $2-8$ times. This is because the phenolic materials can damage the cell membrane, the entocyte flows out, leading to cytolysis, or because of the antidermatophytic mechanism that kills cells gradually (Chan and Yang, 2001). Hwang et al. (2005) indicates that the phenol, 3-methyl-phenol (m-cresol), and 4-

Table 4. Compounds of ether fraction from bamboo vinegars collected at different temperatures

\begin{tabular}{|c|c|c|c|c|c|c|}
\hline Time & Identified compound & \multicolumn{5}{|c|}{ Collected temperature $\left({ }^{\circ} \mathrm{C}\right)$} \\
\hline \multicolumn{7}{|c|}{ Acidic compounds } \\
\hline 2.09 & Acetic acid & 17.22 & 13.26 & 10.57 & 6.28 & 13.60 \\
\hline 2.66 & Propanoic acid & 7.78 & 5.44 & 5.44 & 3.49 & 5.70 \\
\hline \multirow[t]{2}{*}{9.81} & Dehydroacetic acid & 26.74 & 2.94 & - & 2.84 & 3.29 \\
\hline & Total & 26.74 & 23.21 & 17.73 & 12.61 & 23.89 \\
\hline \multicolumn{7}{|c|}{ Phenolic compounds } \\
\hline 7.06 & 4-methyl-phenol (p-cresol) & 4.90 & - & - & - & 0.24 \\
\hline 7.10 & 2-methoxy-phenol & 12.02 & 11.15 & 9.22 & 9.51 & 8.17 \\
\hline 7.52 & 2-ethyl-phenol & - & 0.66 & 0.47 & 0.69 & 2.31 \\
\hline 7.61 & 2,4-dimethyl-phenol & 1.33 & 1.53 & 1.85 & 2.11 & 2.59 \\
\hline 7.70 & 4-ethyl-phenol & 1.16 & 8.00 & 6.28 & 8.08 & - \\
\hline 7.81 & 3,5-dimethyl-phenol & 7.33 & 1.05 & 1.31 & 1.26 & - \\
\hline 7.99 & 2-methoxy-4-methyl-phenol (creosol) & 4.99 & 4.92 & 4.38 & 4.70 & 4.00 \\
\hline 5.07 & 2-methyl-2-cyclopenten-1-one & - & 0.38 & 0.53 & - & 0.35 \\
\hline 5.13 & 1-(2-furanyl)-ethanone & 0.77 & 0.71 & 0.52 & - & 0.36 \\
\hline 5.82 & 3-methyl-2-cyclopenten-1-one & - & - & 0.62 & - & 0.38 \\
\hline 6.53 & 2-hydroxy-3-methyl-2-cyclopenten-1-one & 0.77 & 1.34 & 2.10 & 0.81 & 1.11 \\
\hline 6.63 & 2,3-dimethyl-2-cyclopenten-1-one & - & 1.25 & 1.02 & 1.15 & 1.64 \\
\hline 7.04 & 3-ethyl-2-cyclopenten-1-one & - & - & 0.59 & - & - \\
\hline 7.36 & 3-hydroxy-2-methyl-4H-pyran-4-one (Maltol) & - & - & 0.44 & - & 1.13 \\
\hline 8.57 & 3-methoxy-1,2-benzenediol & 1.09 & 1.13 & 2.19 & - & 1.76 \\
\hline 8.72 & 2,3-dihydro-1H-Inden-1-one & - & - & & - & 0.42 \\
\hline 8.87 & 1,2,3-trimethoxybenzene & - & - & 3.17 & - & 0.25 \\
\hline 10.18 & Butylatedhydroxytoluene & 0.80 & - & - & 0.40 & - \\
\hline 10.26 & 1,2,5-trimethoxy-3-methyl-benzene & 4.40 & - & 1.91 & 2.29 & - \\
\hline 11.53 & 1-(4-hydroxy-3,5-dimethoxyphenyl)-ethanone & 0.46 & 0.55 & - & - & - \\
\hline \multirow[t]{2}{*}{20.02} & $3 \beta, 11 \alpha$-dihydroxy-5 $\beta$-androstan-17-one & 2.29 & 1.06 & - & 4.42 & - \\
\hline & Total & 10.58 & 6.42 & 13.09 & 9.07 & 7.40 \\
\hline
\end{tabular}

-: Trace amount (cannot be measured) 
methyl-phenol (p-cresol) have antidermatophytic activity for Pythium splendens, Fusarium oxysporum, Phytophthora capsici, and Ralstonia solanacearum. Voda et al. (2004) also notes that the phenolic materials react with the sulfhydryl group $(-\mathrm{SH})$ of membrane protein of fungi, so that the permeability of the fungal cell membrane changes, the function is damaged, and the enzyme is denatured, resulting in antidermatophytic activity. Therefore, the main compounds of antidermatophytic activity can be derived from phenolic materials. The higher contents of 2,6-dimethoxy-phenol, 4,5dimethoxy-2-methyl-phenol, and 2-methoxy-phenol are probably the main antidermatophytic compounds.

\section{Organic compounds of the stratified fractions of bamboo vinegars}

After the bamboo vinegar was stratified by ether, the acidic compounds, including acetic, propanoic, butanoic and dehydroacetic acid, were $12.61-26.74 \%$. The phenolic compounds for 62.68-78.32\%, whereby the phenol content was the highest, then 2,6-dimethoxy-phenol and 4-ethyl-2-methoxy-phenol. The neutral compounds were $6.42-13.09 \%$, and the major compounds were 2hydroxy-3-methyl-2-cyclopenten-1-one (Table 4). There were 14 kinds of neutral compounds, but the content of phenolic compounds was the highest, and it increased with temperature; the phenol compounds is highest $(19.55 \%)$ at $120-125^{\circ} \mathrm{C}$, and then 2,6-dimethoxy-phenol (13.15\%), 2-methoxy-phenol (9.51\%), 4ethyl-2-methoxy-phenol (4.81\%) and 2-methoxy-4methyl-phenol (creosol) (4,71\%). The acidic compounds was the lowest after the bamboo vinegar was stratified by ether, likely because some of acidic compounds were dissolved in the water fraction; the phenolic compounds had the highest content (62.68-78.32\%), with phenol as the majority, and then 2,6-dimethoxyphenol and 2-methoxy-phenol.

Table 5 showed the phenolic materials results of phenolic fraction from bamboo vinegars, collected at different temperatures, and stratified by ether. The phenolic materials were about 82.27-94.45\%, in which 2,6dimethoxyl-phenol (27.60-44.66\%) was the majority, and then 2-methoxy-phenol (8.82-15.84\%) and 4ethyl-phenol (7.72-11.15\%), but there was still a small amount of neutral material (7.41-15.13\%).

\section{Antidermatophytic activity of the main com- pounds of phenolic materials}

The antidermatophytic activity of phenolic materials for EF, TM, and TR was related to phenol, cresol, 2,6dimethoxy-phenol, and 2-methoxy-phenolic (Table 5). Thus, the antidermatophytic activity was determined by using the broth microdilution method to obtain the MIC result of the standard compound (Table 6). The MIC of phenol for three dermatophytes was $0.08 \mathrm{mg} / \mathrm{mL}$, that of cresol was $0.16 \mathrm{mg} / \mathrm{mL}$, and the MICs of 2,6-dimethoxyphenol and 2-methoxy-phenol were slightly higher than

Table 6. Minimum inhibitory concentrations $(\mathrm{mg} / \mathrm{mL})$ against dermatophytesof standard compound

\begin{tabular}{lccc}
\hline \multicolumn{1}{c}{ Standard compound } & $\mathrm{EF}^{1)}$ & $\mathrm{TM}$ & $\mathrm{TR}$ \\
\hline phenol & 0.08 & 0.08 & 0.08 \\
cresol & 0.16 & 0.16 & 0.16 \\
2,6-dimethoxy-phenol & 0.63 & 0.16 & 0.63 \\
2-methoxy-phenol & 0.16 & 0.16 & 0.63 \\
\hline
\end{tabular}

1) Same as Table 2

Table 5. Compounds of phenolic and neutral materialsof phenolic fraction from bamboovinegars collected at differenttemperatures

\begin{tabular}{|c|c|c|c|c|c|c|}
\hline \multirow{2}{*}{ Time } & \multirow{2}{*}{ Identified compound } & \multicolumn{5}{|c|}{ Collected temperature $\left({ }^{\circ} \mathrm{C}\right)$} \\
\hline & & 80 & 90-93 & 100 & $120-125$ & $140-145$ \\
\hline \multicolumn{7}{|c|}{ Phenolic material } \\
\hline 5.96 & Phenol & 7.66 & 14.16 & $-{ }^{1)}$ & - & 13.34 \\
\hline 6.95 & 4-methyl-phenol (p-cresol) & 3.82 & 4.54 & - & - & 7.43 \\
\hline 7.05 & 2-methoxy-phenol & 14.72 & 15.84 & 11.31 & 8.82 & 15.47 \\
\hline 7.71 & 4-ethyl-phenol & 11.15 & 8.82 & 9.44 & 10.82 & 7.72 \\
\hline 7.94 & 2-methoxy-4-methyl-phenol (creosol) & 7.41 & 6.12 & 6.72 & 5.15 & 4.74 \\
\hline 8.61 & 4-ethyl-2-methoxy-phenol & 7.69 & 8.14 & 8.64 & 6.42 & 6.40 \\
\hline 9.12 & 2,6-dimethoxyl-phenol & 30.66 & 27.60 & 44.31 & 44.66 & 32.43 \\
\hline \multirow[t]{2}{*}{9.77} & 4,5-dimethoxy-2-methyl-phenol & 7.91 & 7.37 & 11.09 & 6.40 & 6.92 \\
\hline & Total & 91.02 & 92.59 & 91.51 & 82.27 & 94.45 \\
\hline \multicolumn{7}{|c|}{ Neutral material } \\
\hline 10.18 & Butylatedhydroxytoluene & 2.05 & - & - & - & - \\
\hline 10.27 & 3-furancarboxylic acid, 5-ethyl-2,4-dimethyl-, methyl ester & 6.92 & 7.41 & 8.49 & 6.40 & 5.56 \\
\hline \multirow[t]{2}{*}{20.01} & $3 \beta, 11 \alpha$-dihydroxy-5 $\beta$-androstan-17-one & - & - & - & 8.73 & - \\
\hline & Total & 8.97 & 7.41 & 8.49 & 15.13 & 5.56 \\
\hline
\end{tabular}

1) Same as Table 4 
the former two, ranging at $0.16-0.63 \mathrm{mg} / \mathrm{mL}$. The phenol had the best antidermatophytic activity among the four standards, and then the cresol, but the four standards were all with the antidermatophytic activity for three dermatophytes. In the scope of this study, the bamboo vinegars collected at different temperatures were all with the antidermatophytic activity for three dermatophytes. It could be indicated that the temperature at 80 , $90-93,100,120-125$ and $140-145^{\circ} \mathrm{C}$ with the contents of the the phenolic materials after ether stratification were 91.02, 92.59, 91.51, 82.27 and 94.45\% (Table 5).

\section{CONCLUSION}

This study used Maso bamboo vinegars collected at different temperatures to investigate the antidermatophytic activity of vinegars and ether stratification fractions. The $\mathrm{pH}$ value of bamboo vinegars was 2.66-3.80, the specific gravity was $1.005-1.007$, the acidic material content was $6.90-8.61 \%$, the dissolved tar content was $0.30-0.57 \%$, and the color number was $7-11$. The gas chromatography showed that the acidic compounds were $12.61-26.74 \%$, where the main compound was acetic acid; the phenolic compounds were 62.68-78.32\%, and the content of phenol was the highest; the neutral compounds were $6.42-13.09 \%$. The phenolic material of phenolic fraction was $82.27-94.45 \%$ after ether stratification, and the phonel and 2,6-dimethoxyl-phenol were the majority. After ether stratification, the MIC for EF of the ether fraction, and the neutral, phenolic materials at $100^{\circ} \mathrm{C}$ was $0.02-0.31 \mathrm{mg} / \mathrm{mL}$; the MIC for TM was $0.08-0.31 \mathrm{mg} / \mathrm{mL}$ at $120-125^{\circ} \mathrm{C}$; and the MIC for TR was $0.04-0.31 \mathrm{mg} / \mathrm{mL}$ at $80^{\circ} \mathrm{C}$. The MIC of the standard compound-phenol for three dermatophytes was $0.08 \mathrm{mg} / \mathrm{mL}$, that of cresol was $0.16 \mathrm{mg} / \mathrm{mL}$, and the MIC of 2,6dimethoxy-phenol and 2-methoxy-phenol was 0.16$0.63 \mathrm{mg} / \mathrm{mL}$. To sum up, bamboo vinegars and the ether fraction and three fractions (acidic, neutral and phenolic materials) have antidermatophytic activity for EF, TM, and TR, which can be considered for application on treating skin fungal infections after appropriate processing.

\section{AUTHOR CONTRIBUTION}

Han Chien LIN designed this paper and wrote the paper. Shao-Hung WANG performed the MIC experiments and supervised the data analysis. Yi-Han HUANG analyzed the data and statistical processes. Tsang-Chyi SHIAH participated in the design of the study and carried out GC-MS experiments. Gwo-Shyong HWANG supported the bamboo vinegars obtained. Noboru FUJIMOTO supervised the work and provided reference resources. The authors assisted in editing of the manuscript and approved the final version.

\section{REFERENCES}

Benger S., P. Townsend, L. A. Robert and L. Peter 2004 An in vitro study to determine the minimum inhibitory concentration of Melaleuca alternifolia against the dermatophyte Trichophyton rubrum. Science direot, 14(2): 86-91

Chan, C. C. and H. T. Yang 2001 Microbiology. Farseeing Publishing Co, Ltd. pp. 157-182

Cheng, W. W., C. T. Lin, F. H. Chu, S. T. Chang and S. Y. Wang 2009 Neuropharmacological activities of phytoncide released from Cryptomeria japonica. Journal of Wood Science, $\mathbf{5 5}(1): 27-31$

Cheng, H. M. 2011 Study on the clinical trial and mechanism of Xiao-Feng-San in atopic dermatitis. Doctoral program of Chinese Medcine, China Medical University, pp. 33-40

Chuang, P. H., C. W. Lee, J. Y. Chou, M. Murugan, B. J. Shieh and H. M. Chen 2007 Anti-fungal activity of crude extracts and essential oil of Moringa oleifera Lam. Bioresource Technology, 98(1): 232-236

Council of Agriculture 2002 Bamboo Industry Transformation and Revival Project. Council of Agriculture, Executive Yuan, Taiwan ROC

Han, H. W., M. M.-L. Hsu and J. S. Choi 2014 Rapid detection of dermatophytes and Candida albicansin onychomycosis specimens by an oligonucleotide array. BMC Infectious Diseases, 14(1): 1-7

Huang, M. Y. and J. H. Wang 2003 Impact of antibiotic use on fungus colonization in patients hospitalized due to fever. Journal of Microbiology, Immunology and Infection, 36(2): 123-128

Hwang, Y. H., Y. I. Matsushita, K. Sugamoto and T. Marsui 2005 Antimicrobial effect of the wood vinegar from Cryptomeria japonica sapwood on plant pathogenic microorganisms. Journal of Microbiology and Biotechnology, 15(5): 1106-1109

Hwang, G. S., C. L. Ho, H. Y. Yu and Y. C. Su 2006 Bamboo vinegar collected during charcoal making with an earthen kiln and Its basic properties. Taiwan Journal Forest Science, 29(1): 1-15

Hwang, G. S., Y. J. Lin, C. L. Ho and H. Y. Yu 2008 Study on charcoal marking with branches and tops wood of Cryptomeria japonica using an earthen kiln. Abstracts of The 2008 Annual meeting of The Chinese Forest Products Association, pp. 27-33

Ikimoto, T. and O. Ikeshima 2000 Usages of Bamboo Charcoal and Bamboo Vinegar. Nobunkyou Publication pp. 89-149

Kuriyama, A. 1979 A study on the carbonization process of wood. Bullent Forest Product Research Insititute, 304: 7-76

Lin, H. C., Y. Murase, T. C. Shiah, G. S. Hwang, P. K. Chen and W. L. Wu 2008 Application of Moso bamboo vinegar with different collection temperatures to evaluate fungi resistance of Moso bamboo materials. Journal of the Faculty of Agriculture Kyushu University. Japan, 53(1): 107-113

Lin, H. C., Y. L. Kuo, W. J. Lee, H. Y. Yap and S. H. Wang 2016 Antidermatophytic activity of ethanolic extract from Croton tiglium. BioMed Research International, Article ID 3237586 , 6 pages

Ministry of Health and Welfare 2006 Need liver tests when took drugs with terbinafine. Food and drugs consumer newsletter, 61(2): $1-2$

Mu, J., T. Uehara and T. Furuno 2003 Effect of bamboo vinegar on regulation of germination and radicle growth of seed plants. Journal Wood Science, 49: 262-279

Roberts, D. T. 1999 Onychomycosis: current treatment and future challenges. Department of Dermatology, Southern General Hospital, Glasgow 56(5): 1-4

Sugimura, T., S. Sato, M. Nagao, T. Yahagi, T. Matsushima T. and Y. Seino $1976 \quad$ Overlapping of carcinogens and mutagens. Fundam Cancer Preview Process International Symposium Princess Takamatsu Cancer Research Fund $6^{\text {th }} 1975$, pp. $191-215$

Voda, K., B. Boh and M. Vrtacnik 2004 A quantitative structureantifungal activity relationship study of oxygenated aromatic essential oil compounds using data structuring and PLS regression analysis. Journal Molecular Modeling, 10: 76-78

Yatagai M., M. Nishimoto, K. Hori, T. Ohira, and A. Shibata 2002 Termiticidal activity of wood vinegar, its components and their homologues. The Japan Wood Research Society, 48: 338-342 